\title{
Biosafety Issues of Unintended Horizontal Transfer of Recombinant DNA
}

\author{
Getachew Alamnie $^{1^{*},}$ Berhanu Andualem ${ }^{2}$ \\ ${ }^{1}$ College of Natural and Computational Sciences, Department of Biology, Mekdela Amba University, Ethiopia \\ ${ }^{2}$ Institute of Biotechnology, Department of Industrial and Environmental Biotechnology, University of Gondar, \\ Ethiopia
}

*Corresponding Author: Getachew Alamnie, M, College of Natural and Computational Sciences, Department of Biology, Mekdela Amba University, Ethiopia.

\begin{abstract}
Horizontal gene transfer (HGT) is the stable transfer of genetic material from one organism to another without natural reproduction between organisms. Genetic exchange occurs by the transfer of donor genetic material across cellular boundaries, followed by heritable incorporation to the genome of the recipient organism. The first description of a horizontal gene transfer has been a major advance in molecular biology. Microbes acquire DNA from a variety of sources. In addition to conjugation, transformation and transduction, other diverse mechanisms of genetic material uptake occur in nature. Genetically modified organisms (GMOs) often contain recombined genes (transgenes) collected from different species to enable the expression of new traits. Unintended HGT of rDNA to both prokaryotes and Eukaryotes could pose risks to human health, the environment. From the current scientific evidence, HGT from GMOs to other organisms presents negligible risks to human health and safety or the environment due to the rarity of such events relative to those HGT events that occur in nature.
\end{abstract}

\section{INTRODUCTION}

DNA is usually transferred over generations following the normal reproduction pathway of the organism involved and this process is called vertical gene transfer, however, DNA can also more infrequently spread to unrelated species through a process called horizontal gene transfer (HGT) (Li et al., 2019). According to Gao et al. (2019); Lee et al. (2019); Karsten et al. (2017), Adato et al. (2015); Soucy et al. (2015) horizontal gene transfer refers to the transfer of genetic material from one organism to the other organism independent of natural reproduction. It takes place extensively among prokaryotes, plays a key role in the evolution of genomes and has been documented within and between the Archaea, Bacteria, and Eukarya domains as well as viruses. With very rare exception, HGT occurs much less frequently in eukaryotes than in prokaryotes (Hotopp, 2011). Transfer occurs by the passage of donor genetic material across cellular boundaries, followed by heritable incorporation to the genome of the recipient organism (Lee et al., 2019; Karsten et al., 2017).

HGT enables the exchange of genetic material even between distant species mediated usually by transduction, transformation or conjugation (Gyles and Boerlin, 2013). This process can be mediated by the integration of viruses (bacteriophages), transposable elements, or integrative plasmids, often via non-homologous recombination (Soucy et al., 2015).

More recently, concerns have been raised that HGT from genetically modified organisms have adverse effects (Li et al., 2019). HGT of an introduced gene in a GMO may confer a novel trait in another organism, which could be a source of potential harm to the health of people or the environment. Xue et al (2019); Soucy et al. (2015) revealed that genetic engineering became an issue of public health concern through the spread of antibiotic resistance genes amongst pathogenic bacteria and more recently with commercial production of genetically modified crops. Also the study conducted by Lu et al. (2019); Zhang et al. (2019); Guo and Tian (2019) discussed that HGT leading to acquisition or modification of traits as antibiotic resistance, virulence, and nitrogen fixation. So the objective of this review is to assess and explore recent understanding about unintended horizontal transfer of recombinant DNA in eukaryotes and prokaryotes and mainly the possibilities and mechanisms through which foreign DNA can introduce into the organisms and its effect. 


\section{Horizontal Gene Transfer AND THE NATURE OF HEREDity}

The first description of a horizontal gene transfer has been a major advance in molecular biology, and can even be seen as its founding experiment (Soucy et al., 2015). Griffith (1928) showed that nonvirulent pneumococcus bacteria can become pathogenic simply by contact with virulent bacteria even bacteria destroyed by heat, capable of modifying heredity by the process called transformation. Avery et al. (1944) showed that remarkable ability of pneumococci to acquire DNA horizontally and DNA is the heritable material of life. This problem found its solution almost ten years later when Hershey and Chase (1952) showed that bacteriophage T2 injects its DNA, but not proteins upon infection of host bacteria, and when the double-helical filamentous structure of DNA molecules was described by Watson and Crick (1953) these authors proposed genetic information to be contained in the specific sequences of nucleotides.

\subsection{Mechanisms of Horizontal Gene Transfer}

Exchange of genetic material between bacterial species is mediated by the basic processes of conjugation, transduction and transformation (Bellanger et al., 2014; von Wintersdorff et al., 2016). In addition to this there are other mechanisms also involved in the uptake and establishment of genetic material in addition to these. The extraordinary capacity of Agrobacterium to transfer its genetic material to host cell makes it evolve from phytopathogen to a powerful transgenic vector (Guo et al., 2019).

\subsubsection{Transformation}

Mechanism by which free DNA present in the medium typically derived from dead organisms and is taken up into the cytoplasm. This could be mainly for nutritional purposes but some bacteria are very selective on the type of DNA that they allow into the cell, suggesting that it also serves to favor recombination with close relatives (Mell and Redfield, 2014). The transformation mechanism of prokaryotes involves integration of free extracellular DNA that becomes incorporated into the genome (Cabezon et al., 2015; Ilangovan et al., 2017). Prokaryotic genomes are highly dynamic; they are usually replete with HGT, undergoing continuous gains, often from outside the species, genus, or family, and losses through deletion (Puigbo et al., 2014)

\subsubsection{Conjugation}

Is a one-way transmission mechanism of DNA from one cell to another via a "sexual pilus" by which DNA is transported? The study conducted by Kurono et al. (2012); Matsuda et al. (2012) explained that there are interspecies and intergenus transfers of bacterial DNA by conjugation in food/feed and in the intestine. A group of modular mobile genetic elements, known as integrative and conjugative elements (ICEs) or conjugative transposons, has been found in many bacterial genomes (Cury et al., 2017). Some reports have shown that conjugative transfer in food could have relevant safety consequences due to the mobilization of antibiotic resistance and toxin genes (Van der Auwera et al., 2007; Gazzola et al., 2012).

\subsubsection{Transduction}

Transduction is the bacteriophage mediated transfer of host DNA between bacterial cells. This is a mechanism for gene transmission mediated by a bacteriophage that functions both as a reservoir and as a vector of exogenous genes, which remain protected from environmental effects in the bacteriophage capsid (Natalia et al., 2019). Studies of model phage host systems have revealed mechanisms of transduction and have led to the development of sophisticated genetic methods (Bergman et al., 2019).

\subsection{Detecting Patterns of Horizontal Gene Transfer}

Microbes acquire DNA from a variety of sources. The development of genome sequencing, have revealed that horizontal gene transfer has been a major evolutionary force that has constantly reshaped genomes throughout evolution (Ravenhall et al., 2015; Adato et al., 2015; Soucy et al., 2015). There are several approaches to identify genetic changes due to HGT, including:

- Experimental evidence: whereby a genetic marker is monitored for gene transfer to a recipient organism (Frazao et al., 2019)

- Phylogenetic analysis of gene sequences: to identify topological inconsistencies between different gene families (Jeong et al., 2016; Ravenhall et al., 2015; Remigi et al., 2016). 
- Nucleotide compositional analysis: to identify any gene that has a nucleotide pattern that differs significantly from the overall genome (Cheeseman et al., 2014; Adato et al., 2015).

\section{INTRODUCTION TO BIOSAFETY ASPECTS OF RECOMBINANT DNA}

Theoretically, all genes including highly conserved genes such as ribosomal genes appear to be capable of HGT (De Santis et al., 2018). Environmental situations including soil, freshwater, seawater, wastes from industry and animals, plant surfaces, human and animal intestines and saliva and food products may aid HGT (Burmeister, 2015, Trappe et al., 2016). Yanga et al. (2019); Xue et al.(2019) revealed that the transfer of recombinant DNA from genetically modified organisms (GMOs) such as transgenic plants to phytosphere bacteria may occur and thus contribute to the undesirable spread of antibiotic resistance determinants.

Genetically modified organisms (GMOs) often contain recombined genes (transgenes) collected from different species to enable the expression of new traits (Zhang et al., 2019; Guo and Tian, 2019). As outlined in Akbari et al. (2019); Nielsen (2003a) some commonly occurring characteristics of recombinant DNA in GMOs can make their transgenes more likely to be taken up and expressed in unintended host or bacterial cell recipients.

Globally consumers continue to be concerned about the health and environmental consequences of GM foods production (Delmond et al., 2018; Hudson et al., 2015). Attitudes toward GM foods and willingness to consume these products vary across countries and among consumer groups based on demographic, social, economic, psychological, or religious factors (Mathiowetz and Jones, 2016). While public acceptance of transgenic foods in Japan and the European Union is low, but the use of these products in the United States and in some developing countries is fairly high (Zhang et al., 2018). For instance, Prati et al. (2012) found that Italian consumers have a weak intention to consume GM foods. However, De Steur et al. (2010) and Zhu et al. (2018) showed that Chinese consumers are willing to consume GM foods and such willingness is affected by their knowledge of the product and risk perceptions.

\subsection{Principles and Methods of Biosafety in Horizontal Gene Transfer}

In judging the effectiveness of measures intended to ensure biosafety, it may be helpful to know which goals, principles, and methods of biosafety measures have been employed and to evaluate the scientific basis of their effectiveness. Because the natures of risks are largely identical for GMOs and non-GMOs, containment measures to handle these risks are largely identical for both. In the past biosafety measures have evolved step by step and usually based on expert knowledge and experience, but without a unifying set of guiding principles (Wang and Zhang, 2019).

\subsubsection{Safety and Risk Assessment of HGT}

Risk assessment is the first and central step, and includes hazard recognition and identification, understanding of exposure potentials, frequency of occurrence, evaluation of work tasks and equipment, and assigning protective measures to the specific tasks involved. The second principle is biological containment; wherever possible risks for the workers and the environment may be minimized by reducing exposure potentials and their consequences by using attenuated microorganisms. Each form of HGT involves different risk considerations; for genetic engineering, these risks are commonly addressed through legislation (De Santis et al., 2018, Kuiper and Davies, 2010). Assessing risks of HGT of recombinant DNA in foods derived from GM crops involves estimating both the likelihood of transfer of DNA from GM crops to microorganisms or human cells and the impact of such a transfer event. Transformation during the production of silage from GM plants would affect bacteria that enter the intestines of human (De Santis et al., 2018; Codex Alimentarius, 2009; EFSA 2011).

\section{RECOMbINANT DNA InTRODUCTION AND POTENTIAL IMPACT}

The large scale approval, cultivation and consumption of GM commodity crops will necessarily lead to the release and to some extent persistence of recombinant DNA in the environment (Li et al., 2019). DNA is continually released from living organisms, shedding tissues or cells or from their decaying debris (Proia et al., 2016; Li et al., 2019). The release of DNA is therefore not specific to GMOs and the effect thereof should be seen in the context of DNA released from other organisms present in the same natural system (Hu et al., 2019). Evidence obtained both from DNA sequencing of whole organismal genomes and laboratory studies of DNA exchange between organisms demonstrate that 
some, often minor fragments of DNA, can be integrated into the genome of the exposed recipient organism (Thomas and Nielsen, 2005).

Most foreign DNA taken up and integrated into the genome of an organism will have a deleterious effect due to its interference with the host cell biology and genome structure (Doerfler, 2000). HGT processes thus resemble a mutational process, which is they may occur by chance and repeatedly over time but a very low proportion of the HGT events will confer a benefit and be retained in the host over time (Heinemann and Bungard, 2005).

Unintended HGT of rDNA to both prokaryotes and Eukaryotes could pose risks to the environment could be summarized as (1) risks associated with biodiversity including ecosystem functions effects on soil, and non-target species; (2) risks associated with gene flow and genetic recombination; and (3) risks associated with their evolution i.e. development of resistance either in insect pests or in weeds (Tsatsakis et al., 2017). The potential impact of unintended HGT of recombinant DNA from GMOs to exposed organisms must be seen within the broader picture of naturally occurring processes including:

- The continual large scale release of genetically diverse DNA molecules from a broad range of naturally occurring or introduced species in a given environment

- The infrequent and random HGT events occurring naturally in the same environment that the GMO will be released into

- The extremely low likelihood that any DNA taken up will improve the fitness of the exposed host organism

\subsection{Risks Due to Horizontal Gene Transfer}

Genetic engineering has many potential applications in agriculture, therapeutics and industrial chemical production. With these new opportunities has come greater public scrutiny and government regulation. All organisms have a history of HGT and every gene, including those introduced by gene technology, is capable of being transferred between organisms by HGT. A study by Xue et al. (2019); Lu et al. (2019); Zhang et al. (2019); Guo and Tian, (2019); Soucy et al. (2015) discussed that the transferred genes could confer a novel traits to the recipient organisms, which may result in negative, neutral or positive effects

\subsubsection{Gene Flow}

The introductions of non-native GMOs in the ecosystems pose potential long term risks. Environmental implications of gene flow are variable but some of the effects of gene flow could be generalized on the basis of general findings in relevance to many cases, such as development of superweeds, evolution of new viral pathogens, instability of transgenes in the environment, creation of pests and pathogens having resistance to new compounds (Beckie et al., 2012; Yu et al., 2011; Egan et al., 2011). Concomitantly, secondary effects of gene flow also need to be addressed including effects on non-target species, biodiversity disturbance, species displacement and extinction, disturbance in soil microenvironment and species of ecological concern (Layton et al., 2015).

\subsubsection{Antibiotic Resistance}

The spread of Antibiotic resistant bacteria (ARB) and Antibiotic resistance genes (ARG) have become an emerging threat to the global health which have been extensively found in various environments $(\mathrm{Hu}$ et al., 2019; Proia et al., 2016; Li et al., 2019; Li et al., 2015). By this horizontal gene transfer (HGT) is regarded as one of the major pathways leads to the public health concern by exchanging genetic material that expressed in the recipient organism ( $\mathrm{Li}$ et al., 2019). The spread of bacterial antibiotic resistance mainly depends on gene transfer and spontaneous mutation (Lin et al., 2016). Mutagenic factors are thought to be the main reason for the induction of antibiotic resistance in the environment (Lv et al., 2014).

As an alternative, they get mobile genetic factors from other bacteria to obtain antibiotic resistance, which is called horizontal gene transfer (HGT) (Ojala et al., 2014). The intensive application of antibiotics in different areas drive abundant antibiotic resistant bacteria (ARB) and antibiotic resistance genes (ARGs) are frequently detected in environments such as water, soil and even air thus posing a potentially health concern (Chen et al., 2019; Hendriksen, 2019). Antibiotics have received special attention due to their potential to promote and maintain bacterial resistance (Meng et al., 2015). 
Particularly human pathogenic bacteria acquiring antibiotic resistance genes (ARGs) can have severe impacts on human health (Zhang et al., 2016).

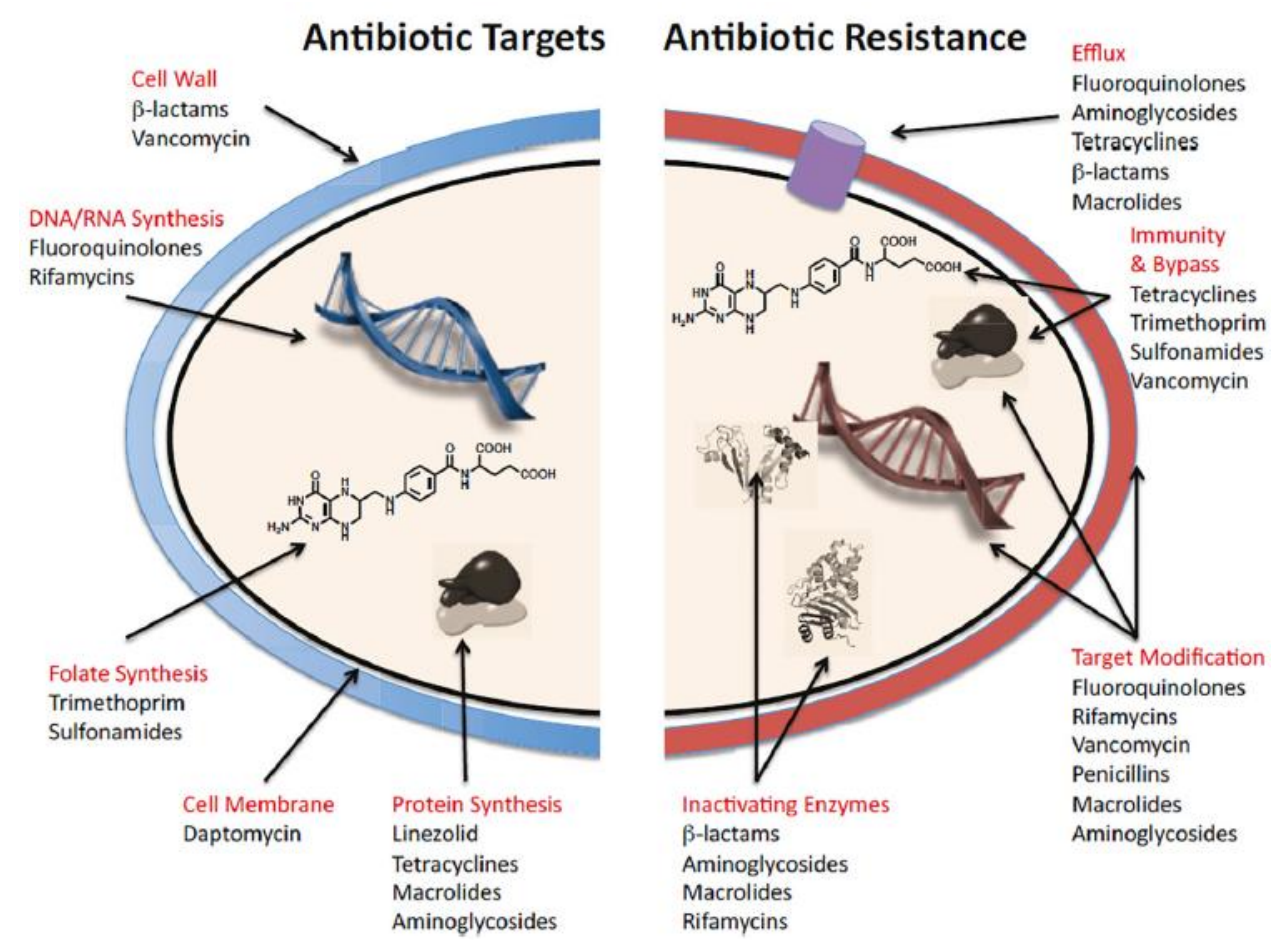

Figure1. Antibiotic targets and examples of resistance mechanisms for selected antibiotics (adapted from Wright, 2010 cited by Pazda et al., 2019).

\subsubsection{Super Weediness}

Recent studies support that domesticated crops could escape from cultivation (ferality) and become a potential weed. Traits like fast growth rate, self-compatibility (crop traits) could favor weediness (Ellstrand et al., 2013; Mercer et al., 2014). A gain of herbicide resistance gene through hybridization with GM plants could lead towards its persistence in the agricultural habitat (Guan et al., 2015). There exists a contradiction among scientists about the establishment of transgene recipient as weeds in the environment. For example, Williamson et al. (1990) reported that small genetic modification through GMO $\times$ domesticated crop hybrids could cause large ecological alterations. Based on the risk of increased fitness, certain traits are strong candidates which can enhance chances of competitiveness, such as tolerance to herbicides, resistance to various stress, pathogens and pests and traits responsible for enhanced growth (Yang et al., 2012). Plants can develop several herbicide-resistance mechanisms, such as herbicide detoxification, changes in the intracellular compartmentation of herbicides, target site insensitivity, reduced herbicide entry, reduced herbicide translocation and target site overproduction (Guan et al., 2015). The risk of pervasiveness or invasiveness is regarded relatively low, there are some possible biological changes that could lead to weediness such as tolerance to extreme regimes of temperature, water and soil salinity, modification in seed propagation and dormancy characteristics and introduction of resistance to pest or pathogens (Tappeser et al., 2014).

\subsubsection{Effect on Biodiversity}

Widespread commercial cultivation of GM crops especially herbicide tolerant crops pose serious threats to the ecosystem complexity and reduction in biodiversity. Likewise, studies showed that the diversity, density, and biomass of the seed bank in farmland were evidently lesser in GM systems contrary to conventional systems (Bohan et al., 2005). Pesticides are often transported beyond crop fields and can show considerable impacts on terrestrial and aquatic ecosystems or on plant populations in the vicinity of crop fields. To a broader sense, it could be concluded that biodiversity is negatively affected by the cultivation of GM crops (Isenring, 2010; Lovei et al., 2010).

\subsubsection{Evolution of Herbicide Resistance Weeds}

On a large geographical scale, many independent evolutionary events could simultaneously interplay for the emergence of herbicide resistance (Bonny, 2016). Regular use of glyphosate on a considerable 
proportion of GM crop fields makes the assumption of glyphosate resistance development a reasonable hypothesis. It is not mandatory for weeds to be a poorer competitor than susceptible weeds as no fitness differential was detectable between susceptible and resistant biotypes (Busi et al., 2013). In tolerance development, various mechanisms could help the plant such as target site over production, modification in intracellular herbicide compartmentation, minimal herbicide absorbance and translocation, herbicide detoxification and insensitivity to target site (Brower et al., 2012).

\subsubsection{Resistance to Insecticide and Pesticide}

Controlling pests through conventional and chemical techniques have been proven to be challenging as evolution of insecticide and pesticide resistance has been witnessed in many cases (Dale et al., 2002). More specifically, the possibility of evolution of Bt-resistant insect pests can't be negated because of constitutive expression of Bt toxins in all plant tissue imparts higher selection pressure on target species (Yu et al., 2011). Use of Bt bio-pesticides by organic farmers lead to resistant diamondback moth populations in Central America, Florida, Japan, Philippines, Hawai, and China (Tabashnik et al., 2013).

\section{HGT OF RECOMbinant DNA to Eukaryotic CELlS}

The uptake of food derived DNA into host intestinal cells or tissues has been raised as a potential concern related to the introduction of GMO based food sources. Such exposure must be seen in relation to the broad variety of DNA naturally present in food and hence, whether specific qualitative or quantitative genetic changes are present in the GMO that would create a higher risk/impact of DNA exposure from this source (Nawaz et al., 2019; Rizzi et al., 2012; Nordgard et al., 2007).

The fate of dietary DNA in the gastrointestinal tract (GIT) of animals has gained renewed interest after the commercial introduction of genetically modified organisms (GMO). Among the concerns regarding GM food, are the possible consequences of horizontal gene transfer (HGT) of recombinant dietary DNA to bacteria or animal cells (Rizzi et al., 2012). The exposure of the GIT to dietary DNA is related to the extent of food processing, food composition, and to the level of intake. Animal feeding studies have demonstrated that a minor amount of fragmented dietary DNA may resist the digestive process (Rizzi et al., 2012; Nordgard et al., 2007).

Feed derived DNA taken up from the gastrointestinal tract and detection in leucocytes, spleen, liver, and kidneys in mice, in the brain, eyes, liver, and heart of the offspring of mice (plasmid DNA), detection in the liver and spleen of mice following feeding with soybean leaves (Hohlweg and Doerfler, 2001), and detection of fragments of plant DNA in muscle, liver, spleen, and kidneys in chicken and cattle (Einspanier et al., 2001). It has been estimated that approximately $0.1 \%$ to $1 \%$ of dietary DNA is absorbed from the gastrointestinal tract (Nielsen et al., 2005a; 2006). A precise measurement of this process is complicated because absorption from the gastrointestinal tract takes place over several hours and absorbed DNA undergoes continuous transport, degradation and elimination. Nevertheless, it is clear that DNA in food may reach the bloodstream and be exposed to and localized to various host cells and tissues (Rizzi et al., 2012).

Biological risk assessment of food containing recombinant DNA has exposed knowledge gaps related to the general fate of DNA in the gastrointestinal tract (GIT). DNA macromolecules are continually introduced into the gastrointestinal tract (GIT) as a natural part of food.

Whereas the majority of feed-derived DNA is broken down during digestion (Palka-Santini et al., 2003; Tony et al., 2003), several studies have now shown that minor proportions of feed-derived DNA survive immediate degradation and reach the bloodstream in various animals (Deaville and Maddison, 2005; Einspanier et al., 2001; Jennings et al., 2002) or are detectable as minor fragments in faeces (Chowdhury et al., 2004; Wilcks et al., 2004). The fate of chromosomal DNA in the gastrointestinal tract (GIT) of humans and animals has recently received increased attention due to the introduction of novel ingredients derived from genetically modified organisms (GMOs) in the food chain (Sharma et al., 2006). Biological risk assessment of GMOs has exposed knowledge gaps related to how DNA is degraded, or survive degradation in various compartments of the GIT (Nordgard et al., 2007).

\subsection{The Gastrointestinal Tract of Human: A Hotspot for Horizontal Gene Transfer}

The human body is generally studied as a single organism, although it functions more as a complex ecosystem since it hosts trillions of bacteria in different body habitats. The GIT alone is inhabited by 1013-1014 bacteria (Sender et al., 2016). There is a gradient in bacterial concentration along the GIT from low concentrations in the stomach and the duodenum (103-104 bacteria/g), increasing in the ileum 
(108 bacteria/g) with the highest bacterial concentrations found in the colon and stools where 1011 bacteria/g are present. Dysbiosis of the gut microbiota is implicated in a wide range of diseases such as inflammatory bowel disease, diabetes, cardiovascular disease, or even autism spectrum disorders (Cho and Blaser, 2012). The dynamics of these bacterial communities is complex. However, one hallmark of these communities is that bacteria can share different phenotypic traits through a transfer of genetic material. This was first described in 1928 by Fred Griffith, when DNA from a virulent bacterial strain (Streptococcus pneumonia) was isolated and mixed with an avirulent form of the bacterium (Griffith, 1928). This was subsequently found to be caused by a mechanism known as horizontal gene transfer (HGT), by which bacteria can share different traits such as antibiotic resistance (van Schaik, 2015).

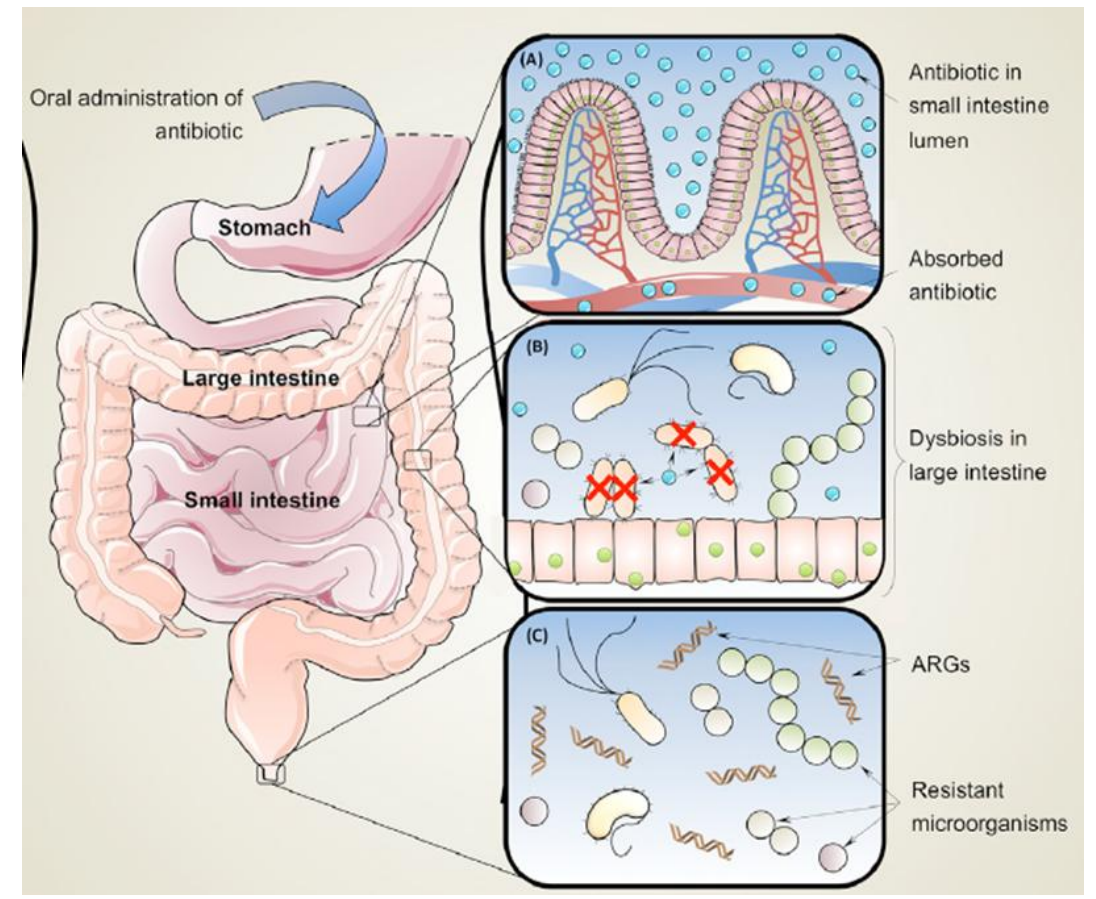

Figure2. (Kelly et al., 2019). Cross-section of the gut showing the absorption of antibiotic following enteral administration followed by antimicrobial resistance (AMR) development in the large intestine. (A) Antibiotic absorption to the systemic circulation through the walls of the small intestine. (B) Selective propagation of resistant gut bacteria following exposure to sub-lethal antibiotic concentrations in the slower moving large intestine. (C) Excretion and spread of resistant bacteria in the feces along with associated antimicrobial resistance genes (ARGs) into the surrounding environment.

\subsection{Human Exposure to Foreign DNA}

Humans are continually exposed to foreign DNA (GM and/or non-GM) from a broad range of food and feed sources including inhaled organisms (e.g. bacteria, viruses, pollen etc.), from a broad variety of food sources including the microorganisms present in food, via microorganisms normally present in and on humans, and infectious agents entering the body. The study conducted by Rizzi et al. (2012) indicated that a few years ago it was assumed that ingested DNA is completely degraded in the digestive tract of humans and animals.

However, with the global commercialization of GM food and feed, there has been a renewed interest in the fate and effects of GM derived extracellular DNA in the body of the consumer. Thus the human body has mechanisms to protect host cells and utilize and degrade or remove foreign DNA molecules. For instance, free bacterial DNA in the blood triggers immune system reactions (Cohen 2002). It is estimated that humans ingest $0.1 \mathrm{~g}$ to $1 \mathrm{~g}$ of DNA per day (Doerfler 2000). The quantity of any recombinant DNA ingested will be a minor fraction of the total DNA consumed per human per day. Transgenes are considered chemically equivalent to any other gene present in food (Jonas et al., 2001).

\subsubsection{DNA in Food}

DNA molecules of broad size ranges are present in large numbers in all raw and unprocessed food sources. Depending on the extent of processing various fractions of DNA molecules of a reduced size may be present in the consumed product. The broad application of sensitive PCR technology has thus exemplified the widespread occurrence and persistence of DNA molecules in various food sources, 
including processed food such as corn chips and chocolate (Rizzi et al., 2004). Thus the overall concentration and distribution of DNA of a size that enables entire protein coding genes to be horizontally acquired from various food sources by host cells or bacteria remains largely undetermined. Studies conducted by Duggan et al. (2003) have demonstrated that the persistence of DNA in food and by Van and Young (2014); Gryson (2010); Kharazmi et al. (2003) revealed that processing often decreases the size of DNA, and such molecules can be undetectable in extensively processed food.

\subsubsection{DNA Stability in the Digestive Tract}

Most free DNA molecules entering the digestive system undergo substantial degradation by enzymes attacking DNA (nucleases, DNases), released from the pancreas and by bacteria present in the intestine (Wilcks et al., 2004). In addition, the low $\mathrm{pH}$ of the stomach may chemically modify the DNA molecules. Remaining DNA fragments are excreted in the faeces with variation in the degradation efficiency between mammals. For instance, Chowdhury et al. (2003a; 2003b) reported that maize DNA could be detected in pig faeces. Study by Netherwood et al. (2004) reported that whereas some DNA fragments survived passage through the small bowel, transgenes could not be detected in the faeces of human volunteer's feed GM soy products.

Most studies on DNA stability in the digestive systems of mammals have used purified DNA and may therefore not capture the impact of various food components, treatments and locations on DNA degradation and stability (Martin-Orue et al., 2002). Although deoxyribonuclease I (DNase I) is detected in saliva, it is believed that DNA digestion starts in the stomach (Liu et al., 2015) where histones are separated from DNA by the action of pepsin (the primary enzyme in the stomach) and the acidity of the environment. DNA is further broken down by gastric acid and DNA nucleases along the GIT and thus only small fragments are presented to intestinal epithelial cells.

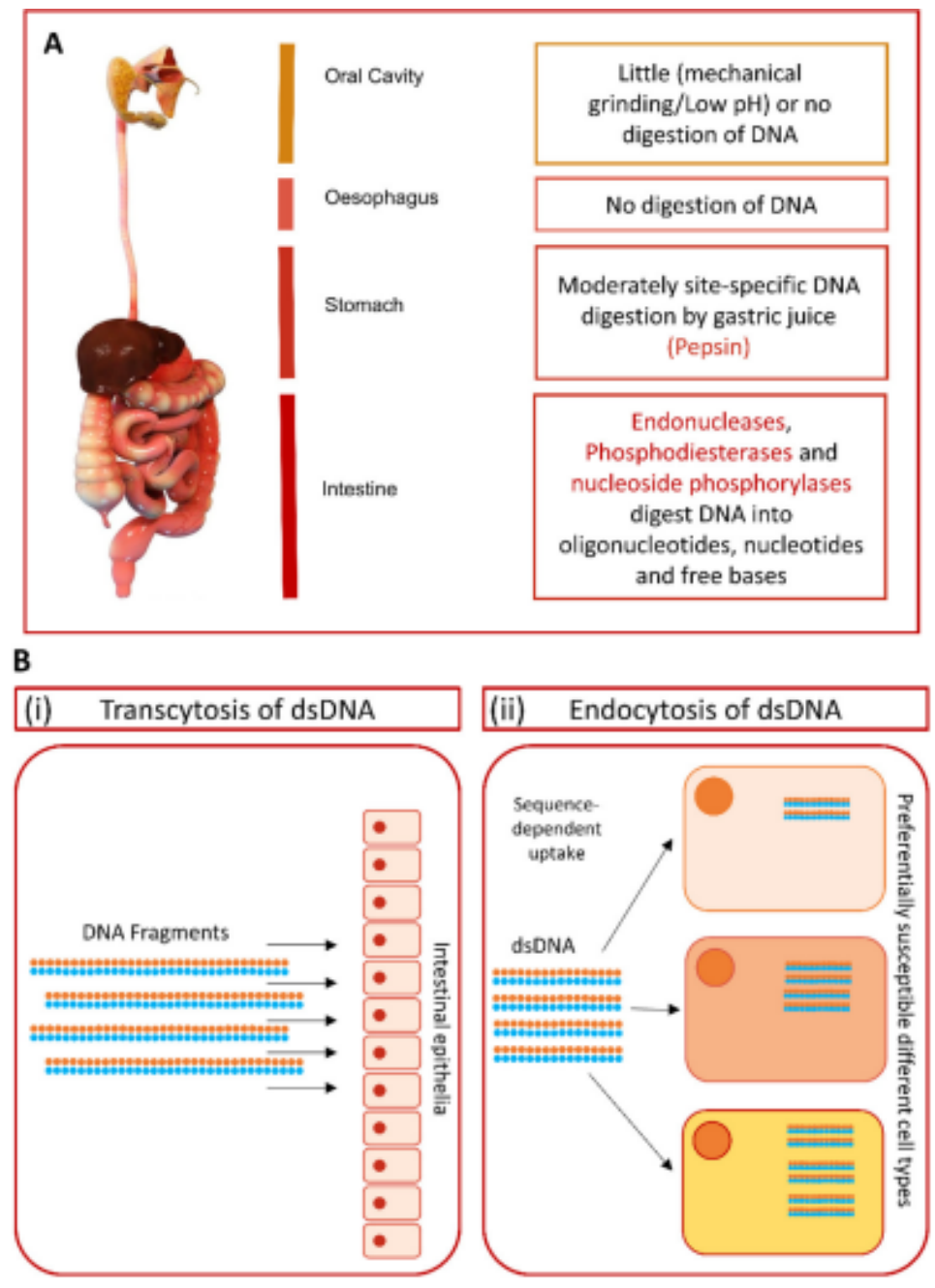

Figure3. A. Fate of extracellular DNA in human digestive system. B. Two possible processes involved in extracellular DNA uptake into the cells. (i) Transcytosis of dsDNA: Uptake of DNA fragments across the intestinal epithelia mediated by vesicular transport. (ii) Endocytosis of dsDNA: Naked dsDNA can be spontaneously 
internalized by sequence dependent mechanism by which genetic information can enter living cells at significant amounts in a bioactive form. The process is also cell type dependent (Nawaz et al., 2019).

\section{HGT of Recombinant DNA to Prokaryotic Cells}

HGT of transgenes into pathogenic beneficial or environmental microorganisms resulting in potential unanticipated fitness effects has been voiced as a potential biosafety issue. A broad range of DNA compositions is continually released from decaying organic matter. Microorganisms are responsible for the majority of organic matter decomposition and therefore also DNA degradation. Thus, microorganisms present in the human gastrointestinal tract and in agricultural environments experience continual exposure to DNA released from themselves and the organisms in their immediate surroundings. DNA fragments exposed to bacteria will most often be utilized as a nutrient source (Nielsen et al., 2007). However, in rare circumstances foreign DNA may also be integrated into the bacterial genome. Experimental studies do not suggest bacteria integrate foreign unrelated chromosomal DNA at measurable frequencies over the limited time span (hours to days) (De Vries et al., 2001; Nielsen et al., 2005).

A high uptake frequency is also unlikely because bacteria are continually exposed to a high diversity of DNA compositions in their environments and unchecked uptake of DNA would quickly reduce the fitness of the bacterium and soon become lethal. Thus, microbial communities are in some cases already exposed to naturally occurring counterparts to these protein encoding genes (Nielsen 2003a; Nielsen et al., 2005). The introduction of similar protein coding genes from recombinant sources to soil is therefore often inferred in biological risk assessments to cause little additional environmental impact, if a HGT event occurred (Nielsen 2003a).

The novelty of the transgenes inserted into GMOs is likely to increase in the future due to development of novel gene constructs (synthetic and artificial bifunctional and multifunctional proteins) obtained through gene fusions, reshuffling and de novo construction of novel protein encoding domains (Nielsen, 2003b).

\section{CONCluding REMARK}

HGT is defined as the transfer of genetic material from one organism to another independent of reproduction. HGT results in unidirectional gene flow, usually of one to several genes from a donor organism to the genome of a recipient organism. Ku and Martin have (Ku and Martin, 2016) indicated that eukaryotes do not acquire genes through continual HGT like prokaryotes.

From the current scientific evidence, HGT from GMOs to other organisms presents negligible risks to human health and safety or the environment due to the rarity of such events relative to those HGT events that occur in nature and the limited chance of providing a selective advantage to the recipient organism. The risk assessment of a transgenic bacterium must consider the potential for transfer of introduced genes to other microorganisms in the environment. (Ku et al., 2015) suggested the risks of gene transfer from GM crops currently commercialized as being negligible and the function, characteristics, and potential health impact of the introduction of different transgenes of microbial origin into commercial GM plants and finally concluded that unintended horizontal gene transfer to bacteria was unlikely to raise health concerns. Transfer of antibiotic resistance marker genes from GM plant to the gut microflora of humans and animals and their expression is most probably a rare event, given the low amounts ingested and degradative conditions in the gastrointestinal tract.

\section{Further Perspectives}

It is important to examine the variable potential risk of GMOs within the context of wider knowledge and case-to-case basis.

- To avoid harm to beneficial organisms, spatial and temporal expression of transgene should be considered

- Laboratory scale studies should be conducted to understand the type of risk and its actual potential in a broader environment or farmland systems of GMOs.

- In regard to the environment related risks case by case risk assessment should be done to make universal judgments targeted to inescapable or invasiveness of transgenes or wild $\times$ GMO hybrids and their progenies. 
- Many of transgenes are already present in the environment so studies should be conducted to investigate the comparative survival of identical genes in GMOs.

- Complex food webs and food supplies should be considered case-by-case before the release of new transgene harboring resistance traits.

- While, analyzing novel expressed proteins or unintentionally expressed proteins, their allergic and toxic effect could be predicted using bioinformatics tools.

\section{REFERENCES}

[1] Adato O, Ninyo N, Gophna U, Snir S. 2015. Detecting Horizontal Gene Transfer between Closely Related Taxa. PLOS Computational Biology; 11(10):1004408.

[2] Akbari M, Ardekani FZ, Pino G, Maleksaeidi H. 2019. An extended model of Theory of Planned Behavior to investigate highly educated Iranian consumers' intentions towards consuming genetically modified foods. Journal of Cleaner Production; 227:784-793.

[3] Beckie H.J., Warwick, S.I. Hall, L.M. Harker K.N. 2012. Pollen-mediated gene flow in wheat fields in western Canada. AgrBioForum; 15: 36-43.

[4] Bellanger, X., Guilloteau, H., Bonot, S., Merlin, C. 2014. Demonstrating plasmid-based horizontal gene transfer in complex environmental matrices: a practical approach for a critical review. Science of the Total Environment; 493:872-882.

[5] Bergman J.M., Fineran P.C, Petty N.K., Salmond G.P.C. 2019. Transduction: The Transfer of Host DNA by Bacteriophages. Encyclopedia of Microbiology (Fourth Edition); 458-473.

[6] Bohan, D.A., Boffey, C.W.H., Brooks, D.R., Clark, S.J., Dewar, A.M., Firbank, L.G., Haughton, A.J., Hawes, C., Heard, M.S., May, M.J., 2005. Effects on weed and invertebrate abundance and diversity of herbicide management in genetically modified herbicide- tolerant winter-sown oilseed rape. Proceeding of the Royal Society; 272:463-474.

[7] Bonny, S., 2016. Genetically modified herbicide-tolerant crops, weeds, and herbicides: overview and impact. Environmental Management; 57:31-48.

[8] Brower, L.P., Taylor, O.R., Williams, E.H., Slayback, D.A., Zubieta, R.R., Ramirez, M.I., 2012. Decline of monarch butterflies overwintering in Mexico: is the migratory phenomenon at risk? Insect Conservation Diversity; 5:95-100.

[9] Burmeister A. 2015. Horizontal gene transfer Evolution. Medical Public Health; 1:193-194.

[10] Busi, R., Neve, P., Powles, P., 2013. Evolved polygenic herbicide resistance in Lolium rigidum by low-dose herbicide selection within standing genetic variation. Evolutionary Applications; 6:231-242.

[11] Cabezon, E., Ripoll-Rozada, J., Pena, A., De La Cruz, F., and Arechaga, I. 2015. Towards an integrated model of bacterial conjugation. FEMS Microbiology Reviews; 39, 81-95.

[12] Cheeseman, K., Ropars, J., Renault, P., Dupont, J., Gouzy, J., Branca, A. 2014). Multiple recent horizontal transfers of a large genomic region in cheese making fungi. Nature Communications; 5:2876.

[13] Chen, H.Y., Chen, R.H., Jing, L.J., Bai, X.M., Teng, Y.G., 2019. A metagenomic analysis framework for characterization of antibiotic resistomes in river environment: application to an urban river in Beijing. Environmental Pollution; 245:398-407.

[14] Cho, I., Blaser, M.J., 2012. The human microbiome: at the interface of health and disease. Nature Reviews Genetics; 13:260.

[15] Chowdhury EH, Kuribara H, Suga K. 2003. Detection of genetically modified maize DNA fragments in the intestinal contents of pigs fed StarLink CBH351. Veterinary and Human Toxicology; 45: 95-96.

[16] Codex Alimentarius, 2009. Foods Derived from Modern Biotechnology. Codex Alimentarius Commission, Joint FAO/WHO Food standards programme, Rome. http://www.fao.org/docrep/011/a1554e/a1554e00.htm.

[17] Cohen, J. 2002. The immunopathogenesis of sepsis. Nature; 420:885-891.

[18] Cury, J., Touchon, M., and Rocha, E. P. C. 2017. Integrative and conjugative elements and their hosts: composition, distribution and organization. Nucleic Acids Research; 45:8943-8956.

[19] De Santis B, Stockhofe N, Jean-Michel Wal, Weesendorp N, Lalles JP, van Dijk J, Kok E, De Giacomo M, Einspanier R, Onori R, Brera C, Bikker P, Jan van der Meulen, G. Kleter D. 2018. Case studies on genetically modified organisms (GMOs): Potential risk scenarios and associated health indicators. Food and Chemical Toxicology. 117:36-65.

[20] De Steur, H., Gellynck, X., Storozhenko, S., Liqun, G., Lambert, W., Van Der Straeten, D., Viaene, J., 2010. Willingness-to-accept and purchase genetically modified rice with high folate content in Shanxi Province, China. Appetite; 54 (1):118-125. 
[21] De Vries J, Meier P, Wackernagel W (2001) The natural transformation of the soil bacteria Pseudomonas stutzeri and Acinetobacter sp. by transgenic plant DNA strictly depends on homologous sequences in the recipient cells. FEMS Microbiology Letters;195: 211-215.

[22] Deaville ER and Maddison BC. 2005. Detection of transgenic and endogenous plant DNA fragments in the blood, tissues, and digesta of broilers. Journal of Agricultural and Food Chemistry; 53: 10268-10275.

[23] Doerfler, W. 2000. Foreign DNA in mammalian systems. Wiley-VCH Verlag GmbH, Wennheim, Germany: 181

[24] Domingues S. and Nielsen, K.M. 2019. Horizontal Gene Transfer: Uptake of Extracellular DNA by Bacteria. Encyclopedia of Microbiology, fourth edition. Academic press: 629-644.

[25] Duggan PS, Chambers PA, Heritage J, Forbes JM. 2003. Fate of genetically modified maize DNA in the oral cavity and rumen of sheep. British Journal of Nutrition; 89: 159-166.

[26] EFSA. 2011. Guidance for risk assessment of food and feed from genetically modified plants. EFSA Journal; 9 (5), 2150-2187.

[27] EFSA, 2013. Review of the strategies for the comprehensive food and feed safety and nutritional assessment of GM plants per se. EFSA Supporting publication EN- 480. ADAS UK Ltd. and Roth Amsted Research. http://www.efsa.europa.eu/en/ supporting/doc/480e.pdf.

[28] Egan, J.F., Maxwell, B.D., Mortensen, D.A., Ryan, M.R., Smith, R.G., 2011. 2,4- Dichlorophenoxyacetic acid (2,4-D)-resistant crops and the potential for evolution of 2,4-D-resistant weeds. PNAS 108, E37. http://dx.doi.org/10.1073/ pnas.1017414108.

[29] Einspanier R, Klotz A, Kraft J, Aulrich K, Poser R, Schwägele F, Jahreis G, Flachowsky G. 2001. The fate of forage plant DNA in farm animals: a collaborative case-study investigating cattle and chicken fed recombinant plant material. European Food Research Technology; 212: 129-134.

[30] Ellstrand, N.C., Meirmans, P., Rong, J., Bartsch, D., Ghosh, A., de Jong, T.J., Haccou, P., Lu, B.R., Snow, A.A., Stewart, C.N., Jr., Strasburg, J.L., van Tienderen, P.H., Vrieling, K., Hooftman, D., 2013. Introgression of crop alleles into wild or weedy populations. Annual Review of Ecology, Evolution and Systematics; 99:325-345.

[31] Frazaoa N , Sousaa A,1, Lässigb M,2, Gordo I. 2019. Horizontal gene transfer overrides mutation in Escherichia coli colonizing the mammalian gut. 116 (36):17906-17915.

[32] Gazzola, S., Fontana, C., Bassi, D., Cocconcelli, P.S., 2012. Assessment of tetracycline and erythromycin resistance transfer during sausage fermentation by culture dependent and -independent methods. Food Microbiology; 30:348-354.

[33] Gryson, N., 2010. Effect of food processing on plant DNA degradation and PCR-based GMO analysis: a review. Analytical and Bioanalytical Chemistry; 396:2003-2022.

[34] Guan, Z.J., Zhang, P., Wei, W., Mi, X., Kang, D., Liu, B., 2015. Performance of hybrid progeny formed between genetically modified herbicide-tolerant soybean and its wild ancestor. Annals of Botany; 7:121128.

[35] Guo M, Ye Y, Gao D, Xu N, Yang J. 2019. Agrobacterium-mediated horizontal gene transfer: Mechanism, biotechnological application, potential risk and forestalling strategy. Biotechnology Advances; 37:259-270.

[36] Gyles C., Boerlin P. 2013. Horizontally transferred genetic elements and their role in pathogenesis of bacterial disease. Veterinary Pathology; 51:328-340.

[37] Heinemann, J., Bungard, RA. 2005. Horizontal gene transfer. Encyclopedia of molecular cell biology and molecular medicine. Meyers, RA (Ed) John Wiley and Sons, $2^{\text {nd }}$ Ed. 223-243.

[38] Helander, H.F., Fändriks, L., 2014. Surface area of the digestive tract-revisited. Scandinavian Journal of Gastroenterology; 49:681-689

[39] Hohlweg U and Doerfler W. 2001. On the fate of plant or other foreign genes upon the uptake in food or after intramuscular injection in mice. Molecular Genetics Genomics; 265: 225-233.

[40] Hotopp, J., 2011. Horizontal gene transfer between bacteria and animals. Trends Genetics; 27:157:163.

[41] Hu, Y., Zhang, T., Jiang, L., Yao, S., Ye, H., Lin, K., Cui, C., 2019. Removal of sulfonamide antibiotic resistant bacterial and intracellular antibiotic resistance genes by UVC-activated peroxymonosulfate. Chemical Engineering Journal; 368:888-895.

[42] Hudson, J., Caplanova, A., Novak, M., 2015. Public attitudes to GM foods. The balancing of risks and gains. Appetite; 92:303-313.

[43] Ilangovan, A., Kay, C. W. M., Roier, S., El Mkami, H., Salvadori, E., Zechner, E. L. 2017. Cryo-EM structure of a relaxase reveals the molecular basis of DNA unwinding during bacterial conjugation. Cell; 169:708-721. 
[44] Jennings JC, Albee LD, Kolwyck DC, Surber JB, Taylor ML, Hartnell GF, Lirette RP, Glenn KC. 2002. Attempts to detect transgenic and endogenous plant DNA and transgenic protein in muscle from broilers fed Yield Gard corn borer corn. Poultry Science; 82: 371-380.

[45] Jonas DA, Elmadfa I, Engel KH, Heller KJ, Kozianowski G, Konig A, Muller D, Narbonne JF, Wackernagel W, Kleiner J. 2001. Safety considerations of DNA in food. Annals of Nutrition Metabolism; 45: 235-254.

[46] Karsten B. Siebera , Robin E. Bromleya , Julie C. Dunning Hotopp. 2017. Lateral gene transfer between prokaryotes and eukaryotes. Experimental Cell Research; 358:421-426.

[47] Kelly A. S., Rodgers M. A., O’Brien C.S., Donnelly F.R., Gilmore F.B. 2019. Antibiotic Delivery Strategies to Reduce Antimicrobial Resistance. Trends in Biotechnology, https://doi.org/10.1016/j.tibtech.2019.10.008.

[48] Kharazmi M, Bauer T, Hammes WP, Hertel C.2003. Effect of food processing on the fate of DNA with regard to degradation and transformation capability in Bacillus subtilis. Systems of Applied Microbiology; 26: 495-501.

[49] Ku, C., Martin, W.F., 2016. A natural barrier to lateral gene transfer from prokaryotes to eukaryotes revealed from genomes: the $70 \%$ rule. BMC Biology: 14, 89.

[50] Kuiper H. A. and Davies H. V. 2010. "The safe foods risk analysis framework suitable for GMOs? A case study," Food Control; 21(12):1662-1676,

[51] Kurono, N., Matsuda, A., Etchuya, R., Sobue, R., Sasaki, Y., Ito, M. 2012. Genome-wide screening of Escherichia coli genes involved in execution and promotion of cell-to-cell transfer of non-conjugative plasmids: rodZ (yfgA) is essential for plasmid acceptance in recipient cells. Biochemistry and Biophysics Research Communication: 421:119-123.

[52] Layton, R., Smith, J., Macdonald, P., Letchumanan, R., Keese, P., Lema, M., 2015. Building better environmental risk assessments. Front. Bioengineering and Biotechnology; 3:110. http://dx.doi.org/10.3389/fbioe.2015.00110.

[53] Lee W.J.2019. Protocol measuring horizontal gene transfer from algae to non-photosynthetic organisms. Methods X; 6: 1564-1574

[54] Li B, Qiub Y, Songc Y, Lina H, Yin H. 2019. Dissecting horizontal and vertical gene transfer of antibiotic resistance plasmid in bacterial community using microfluidics. Environment International; 131:105007.

[55] Li, X., Atwill, E.R., Antaki, E., Applegate, O., Bergamaschi, B., Bond, R.F., Chase, J., Ransom, K.M., Samuels, W., Watanabe, N., Harter, T., 2015. Fecal indicator and pathogenic bacteria and their antibiotic resistance in alluvial groundwater of an irrigated agricultural region with dairies. Journal of Environmental Quality; 44:1435.

[56] Lin, W., Li, S., Zhang, S., Yu, X., 2016. Reduction in horizontal transfer of conjugative plasmid by UV irradiation and low-level chlorination. Water Research; 91:331-338.

[57] Lovei, G.L., Bøhn, T., Hilbeck, A., 2010. Biodiversity, Ecosystem Services and Genetically Modified Organisms. Third World Network, 131 Macalister Road 10400 Penang, Malaysia978-967-5412-13-4.

[58] Lu, J., Wang, Y., Jin, M., Yuan, Z., Bond, P., Guo, J. 2019. Both silver ions and silver nanoparticles facilitate horizontal transfer of plasmid-mediated antibiotic resistance genes, Water Research, doi: https://doi.org/10.1016/j.watres.2019.115229.

[59] Lv, L., Jiang, T., Zhang, S., Yu, X., 2014. Exposure to mutagenic disinfection byproducts leads to increase of antibiotic resistance in Pseudomonas aeruginosa. Environmental Science and Technology; 48:81888195.

[60] Martin-Orue SM, O`Donnell AG, Ariño J, Netherwood T, Gilbert HJ, McMathers JC (2002) Degradation of transgenic DNA from genetically modified soya and maize in human intestinal simulations. British Journal of Nutrition; 87: 533-542.

[61] Mathiowetz, A., Jones, J.M., 2016. Genetically modified grains and the consumer. Ref. Modul. Food Sci. https://doi.org/10.1016/B978-0-08-100596-5.00075-5. Elsevier.

[62] Mell JC, Redfield RJ. 2014. Natural competence and the evolution of DNA uptake specificity. Journal of Bacteriology; 196: 1471-1483.

[63] Meng F, Gao G, Yang T.T, Chen X, Chao X, Na G, Ge L, Huang L.N. 2015. Effects of fluoroquinolone antibiotics on reactor performance and microbial community structure of a membrane bioreactor; Chemical Engineering Journal; 280:448-458.

[64] Mercer, K.L., Emry, D.J., Snow, A.A., Kost, M.A., Pace, B.A., Alexander, H.M., 2014. Fitness of crop-wild hybrid sunflower under competitive conditions: implications for crop-to-wild introgression. PLoS One 9, e109001.

[65] Natalia A. Riquelme, Marcela F. Leon, Javier A. Santander, James P. Robeson 2019. Productive infection and transduction by bacteriophage $\mathrm{P} 1$ in the species Salmonella bongori. Electronic Journal of Biotechnology; 41:9-12. 
[66] Nawaza M, Mesnage R, Aristides M. Tsatsakisd, Kirill S. Golokhvasta, Seung Hwan Yang, Michael N. Antoniouc,, GyuhwaChungb,. 2019. Addressing concerns over the fate of DNA derived from genetically modified food in the human body: A review. Food and Chemical Toxicology; 124:423-430.

[67] Nielsen CR, Berdal KG, Bakke-McKellep AM, Jensen AH (2005) Dietary DNA in blood and organs of Atlantic salmon (Salmosalar L.). European Food Research Technology; 221, 1-8.

[68] Nielsen CR, Holst-Jensen A, Løvseth A, Berdal KG. 2006. Persistence and distribution of intravenously injected DNA in blood and organs of Atlantic salmon (Salmosalar L.). European Food Research Technology; 222, 258-265.

[69] Nielsen K. M. 2003a. An assessment of factors affecting the likelihood of horizontal transfer of recombinant plant DNA to bacterial recipients in the soil and phytosphere. Coll. Biosafety Reviews; 1: 79-103.

[70] Nielsen, K. M. 2003b. Transgenic organisms-time for conceptual diversification? Nature Biotechnology; 21:227-228.

[71] Nielsen, K.M., Bøhn, T., Townsend, J.P., 2014. Detecting rare gene transfer events in bacterial populations. Frontier Microbiology; 4:415.

[72] Nielsen, KM, Johnsen, P, Bensasson, D, Daffonchio, D. 2007. Release and persistence of extracellular DNA in the environment. Environmental Biosafety Research; (in press).

[73] Nordgard L, Nguyen T, Midtvedt T, Benno Y, Traavik Y, Nielsen MK. 2007. Lack of detectable DNA uptake by bacterial gut isolates grown in vitro and by Acinetobacter baylyi colonizing rodents in vivo. Environmental Biosafety Research; 614:9-160.

[74] Ojala, V., Mattila, S., Hoikkala, V., Bamford, J.K.H., Jalasvuori, M., 2014. Evolutionary rescue of bacteria via horizontal gene transfer under a lethal $\beta$-lactam concentration. Journal Global Antimicrobial Resistance; 2:198-200.

[75] Palka-Santini M, Schwarz-Herzke B, Hösel M, Renz D, Auerochs S, Brondke H, Doerfler W. 2003. The gastrointestinal tract as a portal of entry for foreign macromolecules: fate of DNA and proteins. Molecular Genetics and Genomics; 270: 201-215.

[76] Pazda M, Kumirsk J, Stepnowski P, Mulkiewicz E. 2019. Antibiotic resistance genes identified in wastewater treatment plant systems: A review. Science of the Total Environment; 697:134023.

[77] Prati, G., Pietrantoni, L., Zani, B., 2012. The prediction of intention to consume genetically modified food: test of an integrated psychosocial model. Food Quality Preference; 25 (2):163-170.

[78] Proia, L., von Schiller, D., Sànchez-Melsió, A., Sabater, S., Borrego, C.M., Rodríguez Mozaz, S., Balcázar, J.L., 2016. Occurrence and persistence of antibiotic resistance genes in river biofilms after wastewater inputs in small rivers. Environmental Pollution; 210:121-128.

[79] Puigbo, P., Lobkovsky, A.E., Kristensen, D.M., Wolf, Y.I., Koonin, E.V., 2014. Genomes in turmoil: quantification of genome dynamics in prokaryote supergenomes. BMC Biology; 12:66.

[80] Ravenhall, M., Škunca, N., Lassalle, F., and Dessimoz, C. 2015. Inferring Horizontal Gene Transfer. PLOS Computational Biology; 11:1004095.

[81] Remigi, P., Zhu, J., Young, J. P. W., and Masson-Boivin, C. 2016. Symbiosis within symbiosis: evolving nitrogen-fixing legume symbionts. Trends Microbiology; 24:63-75.

[82] Rizzi A, Raddadi N, Sorlini C, Nordgrd L, Nielsen MK, Daffonchio D. 2012. The Stability and Degradation of Dietary DNA in the Gastrointestinal Tract of Mammals: Implications for Horizontal Gene Transfer and the Biosafety of GMOs. Food Science and Nutrition, 52 (2):142-161.

[83] Rizzi A, Sorlini C, Daffonchio D. 2004. Practicality of detection of genetically modified organisms (GMO) in food. AgBiotech Net 6:1N-9N.

[84] Sender, R., Fuchs, S., Milo, R., 2016. Revised estimates for the number of human and bacteria cells in the body. PLoS Biology; 14:1002533.

[85] Sharma R, Damgaard D, Alexander TW, Dugan MER, Aalhus JL, Stanford K, McAllister TA. 2006. Detection of transgenic and endogenous plant DNA in digesta and tissues of sheep and pigs fed Roundup Ready Canola Meal. Journal of Agriculture and Food Chemistry; 54: 1699-1709.

[86] Soucy, S. M., Huang, J., Gogarten, J. P. 2015. Horizontal gene transfer: building the web of life. Nature Reviews Genetics: 16:472-482.

[87] Tabashnik, B.E., Brevault, T., Carriere, Y., 2013. Insect resistance to Bt crops: lessons from the first billion acres. Natural Biotechnology; 31:510-521.

[88] Tony MA, Butschke A, Broll H, Grohmann L, Zagon J, Halle I, Dänike, Schauzu M, Hafez HM, Flachowsky G. 2003. Safety assessment of Bt176 maize in broiler nutrition: degradation of maize-DNA and its metabolic fate. Archives Tierernahr; 57: 235-52. 
[89] Trappe K ,Marschall T, Bernhard Y . Renard. 2016. Detecting horizontal gene transfer by mapping sequencing reads across species boundaries. Bioinformatics; 32:595-604.

[90] Tsatsakis, A.M., Nawaz, M.A., Kouretas, D., Balias, G., Savolainen, K., Tutelyan, V.A., Golokhvast, K.S., Lee, J.D., Yang, S.H., Chung, G., 2017. Environmental impacts of genetically modified plants: a review. Environmental Research; 156:818-833.

[91] Van der Auwera, G.A., Timmery, S., Hoton, F., Mahillon, J., 2007. Plasmid exchanges among members of the Bacillus cereus group in foodstuffs. International Journal of Food Microbiology; 113:164-172.

[92] Van Eenennaam, A.L., Young, A.E., 2014. Prevalence and impacts of genetically engineered feedstuffs on livestock populations. Journal of Animal Science; 92(10):4255-4278.

[93] Van Hoek, A.H.A.M. Mevius, D. Guerra, B. Mullany, P. Roberts, A.P. . Aarts, H.J.M. 2011. Acquired antibiotic resistance genes: an overview. Frontier Microbiology; 2:1-27.

[94] Van, A.E., Young, A., 2014. Prevalence and impacts of genetically engineered feedstuffs on livestock populations. Journal of Animal Science; 92:4255-4278.

[95] von Wintersdorff, C. J., Penders, J., Van Niekerk, J. M., Mills, N. D., Majumder, S., Van Alphen, L. B. 2016. Dissemination of antimicrobial resistance in microbial ecosystems through horizontal gene transfer. Frontier Microbiology; 7:173.

[96] Walsh, M.C., Buzoianu, S.G., Gardiner, G.E., Rea, M.C., Gelencser, E., Janosi, A., Epstein, M.M., Ross, R.P., Lawlor, P.G., 2011. Fate of transgenic DNA from orally administered Bt MON810 maize and effects on immune response and growth in pigs. PLoS One 6 (11), e27177,.http://dx.doi.org/10.1371/journal.pone.0027177.

[97] Wang F, Zhang W. 2019. Synthetic biology: Recent progress, biosafety and biosecurity concerns, and possible solutions. Journal of Biosafety and Biosecurity; 1:22-30.

[98] Wilcks A, Hoek AHAM, Joosten RG, Jacobsen BBL, Aarts HJM. 2004. Persistence of DNA studied in different ex vivo and in vivo rat models simulating the human gut situation. Food Chemical Toxicology; 42: 493-502.

[99] Xue W, Zhou Q, Li F. 2019. Bacterial community changes and antibiotic resistance gene quantification in microbial electrolysis cells during long-term sulfamethoxazole treatment. Bioresource Technology; 294:122170.

[100]Yang, X., Wang, F., Su, J., Lu, B.R., 2012. Limited fitness advantages of crop-weed hybrid progeny containing insect-resistant transgenes $(\mathrm{Bt} / \mathrm{CpTI})$ in transgenic rice field. PLoS One 7, e41220. http://dx.doi.org/10.1371/journal.pone.0041220.

[101] Yanga L, Wena Q, Zhaoa Y, Chena Z, Wanga Q, Burgmann H. 2019. New insight into effect of antibiotics concentration and process configuration on the removal of antibiotics and relevant antibiotic resistance genes. Journal of Hazardous Materials; 373:60-66.

[102]Zhang J, Chen M, Sui Q, Tong J, Jiang C, Lu X, Zhang Y, Wei Y. 2016. Impacts of addition of natural zeolite or a nitrification inhibitor on antibiotic resistance genes during sludge composting. Water Research; 91:1286-1291.

[103]Zhang, T., Hu, Y., Jiang, L., Yao, S., Lin, K., Zhou, Y., Cui, C., 2019. Removal of antibiotic resistance genes and control of horizontal transfer risk by UV, chlorination and UV/ chlorination treatments of drinking water. Chemical Engineering Journal; 358:589-597.

[104]Zhang, Y., Gu, A.Z., Cen, T.Y., Li, X.Y., He, M., Li, D., Chen, J.M., 2018. Sub-inhibitory concentrations of heavy metals facilitate the horizontal transfer of plasmid-mediated antibiotic resistance genes in water environment. Environmental Pollution; 237:74-82.

[105]Zhu, W., Yao, N., Ma, B., Wang, F., 2018. Consumers' risk perception, information seeking, and intention to purchase genetically modified food: an empirical study in China. British Food Journal; 120 (9):21822194.

Citation: Getachew Alamnie, Berhanu Andualem," Biosafety Issues of Unintended Horizontal Transfer of Recombinant DNA " International Journal of Research Studies in Biosciences (IJRSB), 8(1), pp 14-27. DOI: http://dx.doi.org/10.20431/2349-0365.0801003

Copyright: (c) 2020 Authors. This is an open-access article distributed under the terms of the Creative Commons Attribution License, which permits unrestricted use, distribution, and reproduction in any medium, provided the original author and source are credited. 